\title{
IMPACT OF DEBT ACCUMULATION ON THE NIGERIA ECONOMIC GROWTH
}

\author{
Motunrayo Helen FALAYE \\ Department of Economics, \\ College of Social and Management Sciences, \\ Afe Babalola University, Ado-Ekiti, Nigeria.

\section{OGUNDIPE, Adebayo Tunbosun} \\ $(\mathrm{PhD})$., Department of Banking and Finance, \\ College of Social and Management Sciences, \\ Afe Babalola University, Ado-Ekiti, Nigeria.
}

\begin{abstract}
The need for many developing countries to bridge the gap between their savings and investments in order to achieve economic growth is very pertinent in the society of today. This need arises from the dearth of sustainable government revenue channels in the country. Hence, this can inevitably resort to external financing.

This research study investigates the impact of debt accumulation on economic growth in Nigeria. Specifically, this research estimates the long run relationship existing between debt accumulation and economic growth. It also analyses the direction of causality between the variables. The research study uses secondary data covering a time frame of 33 years (1985-2018).

Econometric advances of unit root, co-integration, error correction techniques as well as granger causality tests were deployed to ascertain the order of co-integration and levels of relationships. With the aid of E-views statistical package-version 7.0, robust models for estimating the impact of debt accumulation on the economic growth of Nigeria were developed.

The results revealed that there exist 5 co-integrating equations existing between the variables. It also revealed that debt does not granger cause economic growth, whereas economic growth granger causes debt. The final estimation technique employed in the course of this research study revealed that there exists a negative or an inverse relationship between debt accumulation and economic growth, leading to a decrease in economic growth whenever debt increases. This fulfils a priori expectation as well as conforms to previous literatures on debts.
\end{abstract}

There is no need to wait for debt crisis before starting management of debt. Moreover, management of debt should be part of the economic policies of the nation in its day-to-day activities. In addition, the study recommends that external 
borrowings should be channelled to the real sectors of the economy as against social consumption. The funds should be properly managed in order to avoid wastages and mismatch. More also, mechanism that prevent the diversion of the funds should be implemented.

Key words: Accumulation, Debt, Economic Growth, Co-integration, Granger Causality, Error Correction Model

Cite this Article: Motunrayo Helen FALAYE and OGUNDIPE, Adebayo Tunbosun. Impact of Debt Accumulation on the Nigeria Economic Growth, International Journal of Management, 11(12), 2020, pp 1890-1901.

http://iaeme.com/Home/issue/IJM?Volume=11\&Issue=12

\section{INTRODUCTION}

Countries around the world aim at achieving sustainable economic growth and development. Moreover this is achievable if the country has adequate resources. In imagining countries most especially those in Sub-Sahara African the resources endowment to finance the optimal level of economic growth and development are inadequate. This ploughed with problem of low domestic savings, low tax revenue, low productivity and meagre foreign exchange earnings. Basically, for these reason, many developing countries yearning for economic growth inevitably resort to external financing to bridge the gap between their savings and investments. Trying obtaining Finance from abroad, a country may consider several options: grants, foreign investment and loans (concessional and non-concessional ) in that order, However mix of these capital inflow in varying proportion could be obtained depending on the socio- economic and political situation in a country (World Bank ,2009).

In the law of the modern day, debt has no precise fixed meaning and may be regarded essentially as that which one person legally own to another or an obligation that is enforceable by legal action to make payment of money. It was further stated that countries borrow for two broad categories, macro-economic reason (higher investment higher consumption).

\section{LITERATURE REVIEW}

\subsection{The Concept of Debt}

A debt is seen as the resource or money use in an organization that is not contributed by its owner and does not in any other way belong to them. Its represents liability by a financial means or other formal equivalent. By definition, debt accumulation is debt growth by continuous additions, as of principal and interest. It also means the person accumulating debt is not moneywise or has poor money management. The spread out recognition in the foreign community that excessive foreign indebtedness of many developing countries remains a major setback to their sustained growth and development. When a country is indebted, a larger proportion of public spending and the foreign exchange earnings are absorbed by debt servicing. Increasing activities of servicing debt without debt relief leaves the following three options will emanate to the governments of the debtor countries through, capital taxation, consumption taxation, and Public expenditures reduction. They jointly have significant implications for a rise in the poverty ratio. With a view to raising the public revenue to finance debt servicing, the government may increase th tax on capital and/or its incomes. This encourages capital flight and the investment levels fall. A decline in the levels of investment results in reduction in the level of output, and the Okun's law suggests that the employment would fall (Kemal, 2016). 


\subsection{Debt-Cum Growth Model}

Given the need for larger capital stock and the inadequacy of domestic saving to finance investment that would make this possible, it is necessary that domestic savings should be supplemented by foreign sources; this shifted the issue from whether external funds are useful to developing countries but how much is sufficient to help realize her growth potential. However, the general case for borrowing aboard is to add to financial resources not just to acquire specific resources. It is capable of increasing resources available for investment by complementing export earnings. National income accounting states that, excessive investment expenditure over internal savings equal to surplus of imports over exports. The following identities hold at equilibrium;

$$
\begin{aligned}
& \mathrm{I}-\mathrm{S}=\mathrm{m}-\mathrm{x} \ldots \ldots \ldots \ldots \ldots \ldots \ldots \ldots \ldots \ldots \ldots \ldots \ldots \ldots \ldots \ldots \ldots \ldots \ldots \ldots \ldots \ldots \ldots \ldots \\
& \mathrm{S}-\mathrm{M}=\mathrm{x}-\mathrm{m} \ldots \ldots \ldots \ldots \ldots \ldots \ldots \ldots \\
& \text { Given that: } \mathrm{I}=\text { Investment } \\
& \mathrm{S}=\text { Savings } \\
& \mathrm{M}=\text { Import } \\
& \mathrm{X}=\text { Export }
\end{aligned}
$$

The above equations implies that the domestic resources gap (S $-\mathrm{I})$ is identified to foreign investment or external gap $(\mathrm{x}-\mathrm{m})$, an excess of import over export necessarily implies an excess of resources used by an economy over resources generated by it or an excess of investment in resources generated by it or an excess of investment in relation to domestic savings, this means that need for foreign borrowing overtime is determined by the rate of investment in relation to domestic savings. Therefore, foreign debt is not only the difference between domestic investment and savings but includes the different between export and import.

$$
\begin{aligned}
& \text { id }-\mathrm{s}=\mathrm{m}-\mathrm{x} \ldots \ldots \ldots \ldots \ldots \ldots \ldots \ldots \ldots \ldots \ldots \ldots \ldots \ldots \ldots \ldots \ldots \ldots \ldots \ldots \ldots \ldots \ldots \ldots \ldots \ldots \\
& \mathrm{id}+\mathrm{x}=\mathrm{s}+\mathrm{m} \ldots \ldots \ldots \ldots \ldots \ldots
\end{aligned}
$$

The criteria for the national income to be, is that local investment plus export must equal import plus domestic savings for the balance of payment to reach equilibrium without foreign debt, export must be equal import and domestic investment. Reasons being that part of the increased income will spill over into import (assuming a positive marginal propensity to import). Only single condition for increase in investment without negatively affecting the balance of payment is if exports increase simultaneously in the right proportion or the savings shift upwards or the import shift downward. Therefore, the gaps in the equation three (3) and four (4) above may not be equal, factor proportion may be slow to adjust and substitutability between foreign and domestic resources may be a long drawn out process than the possibility that exist for the shortage of foreign exchange and domestic savings at particular points time as well as overtime (Oke et al, 2012)

\subsection{Economic Growth}

Economic growth is, in a limited sense, an increase of the national income per capita, and it involves the analysis, especially in quantitative terms, of this process, with a focus of the functional relations between the endogenous variables. In a wider sense, it involves the increase in Gross Domestic Product (GDP), Gross National Product (GNP) and National Income (NI), therefore of the national wealth, including the production capacity, expressed in both absolute and relative size, per capita, encompassing also the structural modifications of the economy. 
It could also be estimated that economic growth is the process of increasing the sizes of national economies, the macro-economic indications, especially the GDP per capita, in an ascendant but not necessarily linear direction, with positive effects on the economic-social sector. Typically, economic growth can be positive, negative or zero.

However, economic growth is a complex, long run phenomenon, subjected to constraints like excessive rise of population, limited resources, inadequate infrastructure, inefficient utilization of resources, excessive governmental intervention, institutional and cultural models that make the increase difficult, etc. It is obtained by an efficient use of the available resources and by increasing the capacity of production in a country. It facilitates the redistribution of incomes between population and society (Haller, 2012).

\subsection{Empirical Review}

Jacobo et al (2017) investigates the impact of government debt on GDP in 16 Latin American economies, namely Argentina, Bolivia, Brazil, Chile, Colombia, Costa Rica, Dominican Republic, Honduras, Mexico, Nicaragua, Panama, Paraguay, Peru, Uruguay and Venezuela over a period of about fifty years $(1960$ - 2015). The short-run impact of debt on GDP growth is positive, but decreases to close to zero beyond public debt-to-GDP ratios between 64 and $71 \%$.

Ayadi et al (2008) investigates the impact of the huge external debt, with its servicing requirements, on economic growth of the Nigerian and South African economies. The external debts of Nigeria and South Africa are analysed in a new context utilizing traditional, but innovative, models and econometric techniques. Ordinary least squares (OLS) and generalized least squares (GLS) are both employed in the analysis. Other test results shows, the negative impact of debt (and its servicing requirements) on growth is confirmed in Nigeria and South Africa. However, South Africa is better off than Nigeria in the application of external loans to promote growth. Additionally, foreign debt contributes increasingly to growth up to a point after which its contribution becomes negative in Nigeria (reflecting the presence of non-linearity effects).

Mencinger et al (2014) attempts to empirically explore the transmission mechanism regarding the short term impact of public debt and growth, covering the period 1980-2010, and 'new' member states, covering the period 1995-2010. We employ panel estimation on a generalized economic growth model augmented with a debt variable, while also considering some methodological issues like the problems of heterogeneity and endogeneity.

Amassoma (2011) examined the causal nexus between external debt, domestic debt and economic growth in Nigeria between 1970 and 2009 using a Vector Autoregressive (VAR) and a Vector Error Correction (VEC) models. The variables were tested for stationarity using the Philip Perron and Augmented Dickey Fuller test. The result reveals that the variables are stationary at first difference. Co-integration test was also performed and the result revealed the absence of co-integration between domestic debt and economic growth while the result also revealed the presence of co-integration between external debt and economic growth. The co-integration tests determined the fitness of methodological test for causality. The results of the VAR model shows that there is a bi-directional causality between domestic debt and economic growth while that of the VEC model revealed a unidirectional causality from economic growth to external debt in Nigeria.

Eunji et al (2017) strive to investigate the effect of corruption on the relationship between public debt and economic growth. The pooled ordinary least squares (OLS), fixed effects models and the dynamic panel generalized method of moments (GMM) models (ArellanoBond, 1991) are estimated with data of 77 countries from 1990 to 2014. The empirical results show that the interaction term between public debt and corruption is statistically significant. 
The result establishes the hypothesis that the effect of public debt on economic growth is a function of corruption. The sign of the marginal effect is negative in corrupt countries, but public debt enhances economic growth within countries that are not corrupt, i.e., highly transparent.

Ezeabasili et al (2011) investigates the relationship between Nigeria's external debt and economic growth, between 1975 and 2006. Econometric evidence revealed stationarity of the variables at their first difference while the Johansen co-integration approach also confirms the existence of one co-integrating relationship at the 1 percent and 5 percent level of significance. Additionally, error correction estimates shows that external debt has a decreasing relationship with economic growth in Nigeria. For example, a one per cent increase in external debt resulted in a decrease of 0.027 per cent in Gross Domestic Product, while a 1 per cent increase in total debt service resulted to 0.034 per cent (decrease) in Gross Domestic Product. In addition, the pair-wise Granger Causality test revealed that unidirectional causality exists between external debt service payment and economic growth at the 10 percent level of significance.

Festus et al (2019) sought further evidences on the effect of external debt on economic growth in Nigeria. Time series data on external debt stock, real gross domestic product, trade openness, and gross fixed capital formation as a percentage of GDP as well as data on inflation and exchange rates were obtained from the Central Bank of Nigeria (CBN) Statistical Bulletin and World Bank indicators. The study set out to test for both the long run and short run relationship as well as presenting further evidences on the relationship between external debt and economic growth.

\section{METHODOLOGY}

\subsection{Sources of Data}

The data used for this study will be sourced from World Bank Database, Central Bank Statistical Bulletin and other publications. This study, as previously stated, will cover the period of 33years ranging from $1985-2018$.

\subsection{Estimation Techniques}

\subsubsection{Stationary Test}

This stage of estimation procedure tests the stationarity of the variables employed in the study. It helps to determine the order of integration of the data series by applying the PhillipPeron's unit roots test. It is adopted in order to find the long-term properties of the variables in the study. If the time series are found to be stationary, it means that their variance, mean and covariance are constant overtime and that the result obtained from their analysis is reliable and can be used to predict future economic activities of the economy.

\subsubsection{Co-integration Test}

The second estimation procedure involves the test of the level of co-integration among the data series of the same order through the application of the Johansen co-integration test. The implication is that, if in the long run, two or more series move closely together, whether the series itself is trended, the difference between them is constant. In theory, they can wander arbitrarily far away from each other. According to Johansen \&Juselius (1990), achieving empirical result amount to establishing maximum-likelihood test procedure. The Johansen cointegration model is shown below.

$\lambda$ trace $(r)=-T \Sigma$ In $(1-\lambda \mathrm{t})(5)$

Where; 
$\mathrm{T}=$ number of usable observations,

$\lambda=$ estimated eigenvalue from the matrix;

$\lambda$ trace tests the null hypothesis, which states that the number of distinct co-integrating vector is less than or equal to $q$ as against the general unrestricted alternatives. So rejecting the null hypothesis means that the data series contain unit root and must be differenced at least once to achieve stationarity.

\subsubsection{Error Correction Technique}

The ECM reveals that the change on a variable, at times, is not only dependent on the variable, but also on its own lagged changes. This enables us to induce flexibility by explaining the short run and long run dynamics in a unified manner.

\subsubsection{The Granger Causality Test}

The third stage of the estimation procedure examines the causality between debt and economic growth through the application of the Granger causality test propounded by Engle \& Granger (1989). It focused on determining the nature of relationship between the two variables; that is, to determine whether the direction of the relationship is bi-directional, unidirectional, feedback or no causation between the two variables.

\subsection{Model Specification}

The model can then be specified as follows:

$$
G D P=f(D E B T, I N T R, S A V, I N V)
$$

In explicit form,

$$
G D P=\beta_{0}+\beta_{1} D E B T+\beta_{2} I N T R+\beta_{3} S A V+\beta_{4} I N V+\mu
$$

In $\log$ form,

$$
\ln G D P=\beta_{0}+\beta_{1} \ln D E B T+\beta_{2} I N T R+\beta_{3} \ln S A V+\beta_{4} \ln I N V+\mu
$$

Where:

GDP $=$ Gross domestic product

$\mathrm{DEBT}=\mathrm{Debt}$

INTR $=$ Interest rate

SAV $=$ Savings

$\mathrm{INV}=$ Investment

$\mathrm{u}=$ error term

\section{RESULT DISCUSSION}

The result in table 1 shows that all variables were not significant at levels but significant at their various first differences. Comparing their levels with the ADF unit root statistics and various probabilities, the test statistics shows that the variables are statistically significant at $1 \%, 5 \%$, and $10 \%$ critical values. 
Table 1 Augmented Dickey Fuller Unit Root Test

\begin{tabular}{|l|c|c|c|c|}
\hline \multicolumn{1}{|c|}{ Variables } & $\begin{array}{c}\text { Augmented } \\
\text { Dickey fuller Test }\end{array}$ & $\begin{array}{c}\text { Probability @ 1 } \\
\text { Difference }\end{array}$ & $\begin{array}{c}\text { Order of } \\
\text { Integration }\end{array}$ & $\begin{array}{c}\text { Maximum } \\
\text { Length }\end{array}$ \\
\hline GDP & -3.765210 & 0.0070 & $\mathrm{I}(1)$ & 9 \\
\hline DEBT & -4.012254 & 0.0037 & $\mathrm{I}(1)$ & 9 \\
\hline SAV & -5.802617 & 0.0000 & $\mathrm{I}(1)$ & 9 \\
\hline INV & -4.445108 & 0.0012 & $\mathrm{I}(1)$ & 9 \\
\hline INTR & -9.687812 & 0.0000 & $\mathrm{I}(1)$ & 9 \\
\hline
\end{tabular}

Source: Author's E-views Computation, 2020

\subsection{Co-integration Test}

The trace test and max-eigenvalue test was carried out for GDP, DEBT, SAV, INTR, and INV. In the co-integration test as shown in table 2, it can be observed that the chosen macroeconomic variables are co-integrated. This is indicated by the trace test as the maxeigenvalue shows no co-integrating equation. The trace test discovers the presence of 5 cointegrating equation among the variables which shows that the chosen macroeconomic variables are indeed co-integrated which implies that there is existence of long-run equilibrium relationship existing between the variables.

Table 2 Co-integration Test

Sample (adjusted): 19832017

Included observations: 35 after adjustments

Trend assumption: Linear deterministic trend

Series: GDP DEBT SAV INV INTR

Lags interval (in first differences): 1 to 1

Unrestricted Cointegration Rank Test (Trace)

\begin{tabular}{lllll}
\hline \hline $\begin{array}{c}\text { Hypothesized } \\
\text { No. of CE(s) }\end{array}$ & Eigenvalue & $\begin{array}{c}\text { Trace } \\
\text { Statistic }\end{array}$ & $\begin{array}{c}\mathbf{0 . 0 5} \\
\text { Critical Value }\end{array}$ & Prob. ${ }^{* *}$ \\
\hline \hline None $*$ & 0.555038 & 84.45787 & 69.81889 & 0.0022 \\
At most 1 $*$ & 0.451151 & 56.11605 & 47.85613 & 0.0069 \\
At most 2 & 0.322521 & 35.11841 & 29.79707 & 0.0111 \\
At most 3* & 0.294305 & 21.49024 & 15.49471 & 0.0055 \\
At most 4 & 0.233127 & 9.290211 & 3.841466 & 0.0023 \\
\hline \hline
\end{tabular}

Trace test indicates 5 cointegratingeqn(s) at the 0.05 level

$*$ denotes rejection of the hypothesis at the 0.05 level

**MacKinnon-Haug-Michelis (1999) p-values

Unrestricted Cointegration Rank Test (Maximum Eigenvalue)

\begin{tabular}{lllll}
\hline \hline $\begin{array}{c}\text { Hypothesized } \\
\text { No. of CE(s) }\end{array}$ & Eigenvalue & $\begin{array}{c}\text { Max-Eigen } \\
\text { Statistic }\end{array}$ & $\begin{array}{c}\mathbf{0 . 0 5} \\
\text { Critical Value }\end{array}$ & Prob.** \\
\hline \hline None & 0.555038 & 28.34182 & 33.87687 & 0.1982 \\
At most 1 & 0.451151 & 20.99764 & 27.58434 & 0.2764 \\
At most 2 & 0.322521 & 13.62817 & 21.13162 & 0.3963 \\
At most 3 & 0.294305 & 12.20003 & 14.26460 & 0.1033 \\
At most 4 & 0.233127 & 9.290211 & 3.841466 & 0.0023 \\
\hline \hline
\end{tabular}

Max-eigenvalue test indicates no cointegration at the 0.05 level

* denotes rejection of the hypothesis at the 0.05 level

**MacKinnon-Haug-Michelis (1999) p-values 


\subsection{Granger Causality Test}

Following the analysis below, it is evident that DEBT does not granger cause GDP but GDP granger causes DEBT. This means that a uni-directional relationship exists between DEBT and GDP. The same relationship can be found between INV and GDP as INV granger causes GDP but GDP does not granger cause INV. This also applies for INTR and GDP as INTR does not granger cause GDP but GDP granger causes INTR. Another uni-directional relationship can be found between SAV and DEBT as SAV does not granger cause DEBT but DEBT granger causes SAV. Likewise, INV does not granger cause DEBT but DEBT granger causes INV, leading to a uni-directional relationship as well. This can also be found between INTR and DEBT as INTR does not granger cause DEBT but DEBT does granger cause INTR. Similarly, INTR does not granger cause INV but INV granger causes INTR. This shows a uni-directional relationship between the two variables.

This is different for SAV and GDP as they both granger cause each other meaning that a bi-directional relationship exists between SAV and GDP. Similarly, INV granger causes SAV just as much as SAV granger causes INV. This shows a bi-directional relationship existing between them. The same relationship can be found in INTR and SAV as they both granger cause each other

Table 3 Granger Causality Test

Pairwise Granger Causality Tests

Sample: 19812018

Lags: 2

\begin{tabular}{|c|c|c|c|}
\hline Null Hypothesis: & Obs & F-Statistic & Prob. \\
\hline $\begin{array}{l}\text { DEBT does not Granger Cause GDP } \\
\text { GDP does not Granger Cause DEBT }\end{array}$ & 36 & $\begin{array}{l}0.25620 \\
1.24585\end{array}$ & $\begin{array}{l}0.7756 \\
0.3017\end{array}$ \\
\hline $\begin{array}{l}\text { SAV does not Granger Cause GDP } \\
\text { GDP does not Granger Cause SAV }\end{array}$ & 35 & $\begin{array}{l}0.79075 \\
7.38526\end{array}$ & $\begin{array}{l}0.4627 \\
0.0025\end{array}$ \\
\hline $\begin{array}{l}\text { INV does not Granger Cause GDP } \\
\text { GDP does not Granger Cause INV }\end{array}$ & 35 & $\begin{array}{l}2.50147 \\
0.51364\end{array}$ & $\begin{array}{l}0.0989 \\
0.6035\end{array}$ \\
\hline $\begin{array}{l}\text { INTR does not Granger Cause GDP } \\
\text { GDP does not Granger Cause INTR }\end{array}$ & 36 & $\begin{array}{l}0.35080 \\
2.59475\end{array}$ & $\begin{array}{l}0.7069 \\
0.0908\end{array}$ \\
\hline $\begin{array}{l}\text { SAV does not Granger Cause DEBT } \\
\text { DEBT does not Granger Cause SAV }\end{array}$ & 35 & $\begin{array}{l}0.31864 \\
0.66417\end{array}$ & $\begin{array}{l}0.7296 \\
0.5221\end{array}$ \\
\hline $\begin{array}{l}\text { INV does not Granger Cause DEBT } \\
\text { DEBT does not Granger Cause INV }\end{array}$ & 35 & $\begin{array}{l}0.11732 \\
2.96578\end{array}$ & $\begin{array}{l}0.8897 \\
0.0668\end{array}$ \\
\hline $\begin{array}{l}\text { INTR does not Granger Cause DEBT } \\
\text { DEBT does not Granger Cause INTR }\end{array}$ & 36 & $\begin{array}{l}0.39967 \\
1.00949\end{array}$ & $\begin{array}{l}0.6739 \\
0.3761\end{array}$ \\
\hline $\begin{array}{l}\text { INV does not Granger Cause SAV } \\
\text { SAV does not Granger Cause INV }\end{array}$ & 35 & $\begin{array}{l}3.65651 \\
0.81593\end{array}$ & $\begin{array}{l}0.0379 \\
0.4518\end{array}$ \\
\hline $\begin{array}{l}\text { INTR does not Granger Cause SAV } \\
\text { SAV does not Granger Cause INTR }\end{array}$ & 35 & $\begin{array}{l}1.11313 \\
2.57446\end{array}$ & $\begin{array}{l}0.3417 \\
0.0929\end{array}$ \\
\hline $\begin{array}{l}\text { INTR does not Granger Cause INV } \\
\text { INV does not Granger Cause INTR }\end{array}$ & 35 & $\begin{array}{l}0.16333 \\
1.35929\end{array}$ & $\begin{array}{l}0.8501 \\
0.2722\end{array}$ \\
\hline
\end{tabular}




\subsection{Error Correction Model (ECM)}

From the result in table 4, it can be observed that R-squared equals 0.91 . This shows that the chosen independent variables significantly explain changes in the gross domestic product to the tune of $91 \%$. The co-efficient of the adjusted R-squared equals 0.82 which confirms this significant explanation of the extent to which the chosen independent variables explain changes in the chosen dependent variable. The Durbin-Watson statistics equals 1.98 which explains the co-efficient of serial correlation of the error term shows that serial correlation is not an issue in the model. This is indicated by the F-statistics and its probability which equals 0.000241 .

Coming down to the result in table 4, it is observed that economic growth (GDP) is the dependent variable. The variable of interest in this study, the coefficient of debt in the current period is seen as $2.08 \mathrm{E}+10$. The sign is positive showing that the debt might have been used for the right reasons such as the construction of capital projects, etc. Thus, the variable can be said to be statistically significant as 1 unit of debt will increase economic growth by $2.08 \mathrm{E}+10$. In the first lag, the coefficient of debt is given as -0.711684 . Debt is found be negatively related to economic growth and is thus statistically significant in the first lag as these funds when borrowed where used for fraudulent practices. Also, this can be further explained as a 1 unit increase in debt will decrease economic growth by -0.711684 .

Similarly, the coefficient of interest rate (INTR) in the current period is seen as -0.517072 . Interest rate (INTR) negatively affects economic growth. This is shown by the direction of sign between the variables. On the basis of magnitude of the co-efficient, it is observed that when there is a 1 unit increase in INTR, the economy shrinks by about- 0.517072 in the current period. The result for the current is statistically significant and thus, this relationship between INTR and economic growth is apriori expected.

From the result of the current period lag of savings (SAV), it shows that saving is positively related to economic growth in the current period. This is seen as the coefficient of savings in the current period is $3.77 \mathrm{E}+09$. Therefore, the coefficient is shown to be positive and significant. On the basis of magnitude of the coefficient, it is observed that when there is a 1 unit increase in savings, the economy improves by $3.77 \mathrm{E}+09$ in the current period.

However, the coefficient of investment (INV) in the current period is 0.022250 . The coefficient has a positive sign stating that investment contributes positively to economic growth in the current period. Thus, on the basis of the magnitude of the coefficient, a 1 unit increase in investment will improve the economy by 0.022250 . Thus, the variable is statistically significant.

Though interest rate, savings and investment all in the first lag period follow a priori expectation on the basis of the sign, they are not statistically significant at any of the $1 \%, 5 \%$ or $10 \%$ significance levels.

The error correction result shows that the model is overall significant. This is seen as the coefficient of the ECM is -0.007143 which shows that it is negative, and thus follows a priori expectation. The probability of the ECM also conforms to economic theories as it is below $5 \%$ significance level.

This research study set out to estimate the impact of debt accumulation on economic growth in Nigeria by examining the long run relationship between debt accumulation and economic growth, determining the causal link between debt accumulation and economic growth and measuring the impact of debt accumulation on economic growth in Nigeria. The results revealed that there exist 5 co-integrating equations existing between the variables. It also revealed that debt does not granger cause economic growth, whereas economic growth granger causes debt. The final estimation technique employed in the course of this research 
study revealed that there exists a negative or an inverse relationship between debt and economic growth, leading to a decrease in economic growth whenever debt increases. This fulfils a priori expectation as well as conforms to previous literatures on debts. Hadhek Z. \&Mrad F., (2014) in their research work concluded that the main result of their study shows a negative interaction between external debt and investment in 19 developing countries. They went further to conclude, without confirmation that these analysis allowed us, even in part, to show the existence of a relationship between external debt and economic performance of countries. Anyanwu J. C. \&A. E. O. Erhijakpor (2015) also discovered in the course of their study that current domestic debt outstanding as a ratio of GDP has a significantly negative effect on economic growth, due largely to high domestic implicit interest rates. Their results show that, on average, a one percent increase in current domestic debt outstanding reduces economic growth by 0.38 percent. On the other hand they also affirmed that, past domestic debt accumulation positively and significantly affects economic growth - one a percent increase in past accumulated domestic debt increases economic growth by 0.30 percent - thus rejecting the domestic debt overhang hypothesis.

Table 4 ECM test

Dependent Variable: DGDP

Method: Least Squares

Sample (adjusted): 19852006

Included observations: 22 after adjustments

\begin{tabular}{lllll}
\hline \hline \multicolumn{1}{c}{ Variable } & Coefficient & Std. Error & t-Statistic & Prob. \\
\hline \hline C & $-5.01 \mathrm{E}+09$ & $3.34 \mathrm{E}+09$ & -1.500279 & 0.1617 \\
DGDP(-1) & 0.937192 & 0.245499 & 3.817498 & 0.0017 \\
DDEBT & $2.08 \mathrm{E}+10$ & $1.06 \mathrm{E}+10$ & 1.950214 & 0.0701 \\
DDEBT(-1) & -0.711684 & 0.214269 & -3.321453 & 0.0024 \\
DINTR & -0.517072 & 0.271389 & -1.905280 & 0.0664 \\
DINTR(-1) & $1.69 \mathrm{E}+08$ & $1.45 \mathrm{E}+08$ & 1.165026 & 0.2687 \\
DSAV & $3.77 \mathrm{E}+09$ & $1.77 \mathrm{E}+09$ & 2.126100 & 0.0505 \\
DSAV(-1) & 0.147610 & 0.415566 & 0.355203 & 0.7292 \\
DINV & 0.022250 & 0.012698 & 1.752253 & 0.1075 \\
DINV(-1) & 0.011485 & 0.015116 & 0.759801 & 0.4633 \\
ECM(-1) & -0.007143 & 0.003095 & -2.307762 & 0.0299 \\
\hline \hline R-squared & 0.907709 & \multicolumn{2}{c}{ Mean dependent var } & $7.39 \mathrm{E}+09$ \\
Adjusted R-squared & 0.823808 & S.D. dependent var & $1.80 \mathrm{E}+10$ \\
S.E. of regression & $7.55 \mathrm{E}+09$ & Akaike info criterion & 48.63403 \\
Sum squared resid & $6.27 \mathrm{E}+20$ & Schwarz criterion & 49.17956 \\
Log likelihood & -523.9744 & Hannan-Quinn criter. & 48.76254 \\
F-statistic & 10.81884 & Durbin-Watson stat & 1.984100 \\
Prob(F-statistic) & 0.000241 & & \\
\hline \hline
\end{tabular}

\section{CONCLUSION AND RECOMMENDATIONS}

This study examined the contribution of debt accumulation to the economic growth of Nigeria and concludes that debt accumulation contributes negatively to Nigeria's economic growth. The conclusion is drawn based on the findings of the study which accept the null hypothesis that debt accumulation does not contribute to economic growth of Nigeria. All things being equal, debt should impact positively on economic growth. But, in the Nigerian economic situation, debt accumulation was growing without any growth in the economy. This is evident as there are no infrastructures and poor institutions have to raise huge amounts of capital in 
order to provide the basic amenities they may require even before starting out their business. The impact of debt accumulation is not positively felt in Nigeria due to the fact that the funds are not always channeled to the real productive sectors, instead they are mismanaged and mismatched and diverted to private hands.

Therefore, there is the need to struggle for the cancellation of the external debts of the country with the limited possibilities of paying them off without putting the burden on the suffering to heighten the burden debt servicing under the new condition the condition.

Conclusively, it must be realized that a debt is a debt whether it is rescheduled, refinanced or remoulded; it has to be paid, for a country to be permanently relieved.

Based on this conclusion, it is therefore recommended that;

Emphasis should be laid on the need for domestic resource mobilization through savings. There is a positive correlation between domestic mobilization on the one hand and the ability to attract external financial flow including foreign client investment on the other hand. Policies that promote expert and discourage imports should be fully and consistently implemented. To eradicate the adverse effects of debt, management of debt should be part of the macroeconomic policies of the month. Debt management should be part of the economic policies of the nation in its day-to-day activities. Furthermore, accurate information on debts should be sourced as this aids its efficient management on a day-today basis and borrowing strategies in the planning framework. The gap between the creditors and debtors should be narrowed by the application of emerging market oriented management options.

\section{REFERENCES}

[1] Ajayi L. B. \& Oke M. O., (2012). "Effect of External Debt on Economic Growth and Development of Nigeria." International Journal of Business and Social ScienceVol. 3 No. 12 [Special Issue - June 2012].

[2] Ayadi F. S. \& F. O. Ayadi (2008). "The Impact of External Debt on Economic Growth: A Comparative Study of Nigeria and South Africa." Journal of Sustainable Development in Africa (Volume 10, No.3, 2008) ISSN: 1520-5509.

[3] Eunji K., Yoonhee Ha and Sangheon K. (2017).”Public Debt, Corruption and Sustainable Economic Growth."

[4] Ezeabasili V. N., H. O. Isu\& J. N. Mojekwu (2011). "Nigeria's External Debt and Economic Growth: An Error Correction Approach." International Journal of Business and Management Vol. 6, No. 5; May 2011.

[5] Festus, G. E. and Saibu, M. O. (2019)."Effect of external debt on Nigerian Economy: Further evidences."

[6] Kanu, S. I., Anyanwu, F. A. \& Osuji, J. I. (2014).“ The Impact of Disaggregated Components of External Debt on the Economic Development of Nigeria (1969-2011)."Research Journal of Finance and Accounting ISSN 2222-1697 (Paper) ISSN 2222-2847 (online) Vol.5, No.10, 2014.

[7] Kemal A. R., (2016). "Debt Accumulation and Its Implications for Growth and Poverty." The Pakistan Development Review 40:4 Part I (Winter 2001) pp. 263-281.

[8] Mencinger O. S. and Amassoma T. S. (2014). "External Debts and Economic Growth in Nigeria: An Empirical Study Using Autoregressive Distributed Lag Model.”

[9] Nwannebuike U. S., U. J. Oke and O. I. Onuka (2016). "External Debt and Economic Growth: The Nigeria Experience." European Journal of Accounting Auditing and Finance Research Vol.4, No.2, pp.33-48, February 2016. 
[10] Omotosho, Babatunde S.; Jacobo T. \& Doguwa, Sani I. (2016). "Determining the Optimal Public Debt Threshold for Nigeria."CBN Journal of Applied Statistics ISSN 2476-8472,

[11] Onakoya A. B. \& Ogunade, A. O. (2017).“External Debt and Nigerian Economic Growth Connection: Evidence from Autoregressive Distributed Lag Approach.” Journal of Economics and Development Studies March 2017, Vol. 5, No. 1, pp. 66-78 ISSN: 2334-2382 (Print), 2334-2390 (Online).

[12] Onyekwelu U. L., E.Okoye \& U. B. Ugwuanyi (2014). "External Debts Management Strategies in Developing Economies: An Impact Assessment on Selected Economic Indices of Nigeria (2002-2011)."International Journal of Economics and Finance Vol. 6, No. 8; 2014 ISSN 1916-971X E-ISSN 1916-9728.Vol. 7, Iss. 2, pp. 1-25. 